\title{
Effects of Industrial Conflicts on Employees' Performance in a Private Sector Organisation (A case of Ikeja Electricity Distribution Company Plc)
}

\author{
Ibukun Olorunisola Kolawole, PhD. \\ Department of Industrial Relations and Human Resource Management \\ Lagos State University, Ojo
}

\begin{abstract}
The purpose of this study is to investigate effect of industrial conflict on employee' performance in a private sector organisation, a case of Ikeja Electricity Distribution Company Plc (Previously a public corporation conceded to the public by the government under its deregulation and privatisation scheme). This study adopted a survey research design. A total of 100 hundred respondents were selected for the study using stratified sampling techniques. Questionnaire was used to collect primary data. Data collected were analysed using Excel, statistical methods and descriptive statistics. Correlation analysis was to measure the degree of relationship between the independent variable and the dependant variables. Frequencies, percentage mean scores were used in analysing the data with mean scores ranging on a Likert's 5- scale (1 strongly disagree, 2 disagree, 3 neutral, 4 agree, 5 strongly. The findings revealed that poor management of conflict arising from and inter-organisation and intragroup relations and individual employees as well as ineffective conflict resolution procedures affect employees' performance. It was recommended that organisations should improve on their human resources practices and also put good strategic planning in place to be more proactive in handling conflicts. Furthermore, management should ensure that the company has effective policy framework that will address conflicts and create harmonious relationship with the Unions. This may to some extent minimize work place conflicts in the organization and increase employees' performance.
\end{abstract}

Keywords: Employee performance, Ikeja electricity distribution company, Industrial conflict, Private sector organisation

DOI: $10.7176 / \mathrm{EJBM} / 11-24-13$

Publication date: August $31^{\text {st }} 2019$

\subsection{Introduction}

Many businesses, more especially in this time of globalization are operating in a turbulent environment where organisations are searching for the best possible measures that will allow them to improve their performance and competitiveness. Organisations, one time or the other experience conflicts and this makes conflict inevitable. Although conflict in an organization is inevitable, it should be taken into cognisance that friction between the employers and their employees must be reduced through a vibrant collective bargaining process to ensure smooth running of the organization.

In many organizations in Nigeria today, internal (intra-personal) and interpersonal conflicts are consuming so much organizational time and attention that organizations are starting to look as though conflict is their primary business (Ojielo, 2002). Conflicts are an everyday phenomenon in each organisation. According to Esquivel and Kleiner, (1997), conflict is generally regarded as the disagreement regarding interest and ideas. Conflict usually arises as a result of argument or disagreement between two parties and characterized by the inability of those concerned to iron out their differences. Conflict is by nature universal and ubiquitous and inevitable in human existence (Fajana, 2009). The concept of industrial relations involves an exchange relationship between two major actors namely, employers and employees, as well as the intervening role of the state. Suffice it to say that conflict is a product of human interaction and relations. Industrial conflict can therefore be defined as the inability of these parties (either between employer and employees or within their groups) to reach agreement on any issue connected with the object of employer-employee interaction, whether or not this inability results in strikes or other forms of protests.

Employees occupy a very strategic position in an organization because of their crucial roles to the production process. They contribute immensely in the achievement of various organization goals and objectives. However, for employees to perform their tasks effectively and efficiently there must exist a strong cordial relationship between the employers and employees. Fajana, (2002), separated industrial conflict from other forms of conflict to refer to the powerlessness of the employers and employees to arrive at common agreement on any issue connected with employer-employees; interactions. Ongori, (2009), in his own view said that conflict is a fact of life in an organisation as long as people compete for jobs, resources, power, recognition and security. In addition, dealing with conflicts is a great challenge to management (Adomi and Anie, 2005). Conflict commonly arise when employees interact in organisation and compete for scarce resources. Conflicts 
have both negative and positive outcomes to the individual employees and the organisation as well.

The purpose of this study is to investigate effect of industrial conflict on employee' performance in a private sector organisation, a case of Ikeja Electricity Distribution Company Plc (Previously a public corporation conceded to the public by the government under its deregulation and privatisation scheme). Its services are relied on by over 7000 people and the staff strength is currently 3761 and hence investigating the levels of industrial conflict and how this affects the employees' performance is necessary for the timely mitigation procedures to be initiated.

\subsection{REVIEW OF LITERATURE \\ 2.1 The Concept of Conflict}

The term "Conflict" has no single clear meaning. Much of the confusions has been created by scholars in different disciplines who are interested in the study of conflict. Review of literature shows a conceptual sympathy for, but little consensual endorsement of any general accepted definition of conflict. Rahim (2015), opine that "There is tremendous variance in conflict definitions that include a range of definition for specific interest and a variety of general definitions that attempt to be all-inclusive".

While no single definition of conflict exists, most definitions involve the following factors: there are at least two independent groups, the groups perceive some incompatibility between themselves, and the groups interact with each other in some way. Wall and Callister (1995) gave two examples of definitions of conflict which are, "process in which one party perceives that its interests are being opposed or negatively affected by another party" and "the interactive process manifested in incompatibility, disagreement, or dissonance within or between social entities.

Rahim, (2015), said that organisational conflict is now considered normal and legitimate; it may even be a positive indicator of effective organisational management. Within certain limits, conflict can be essential to productivity. Conflict has benefits: it may lead to solutions to problems, creativity, and innovation. In contrast, little or no conflict in organisations may lead to stagnation, poor decisions, and ineffectiveness. Conflict is inevitable among humans. It is a natural outcome of human interaction that begins when two or more social entities engage one another while striving to attain their own objectives. Relationships among people or organisations become incompatible or inconsistent when two or more of them desire a similar resource that is in short supply; when they do not share behavioural preferences regarding their joint action; or when they have different attitudes, values, beliefs, and skills.

According to Rahim, (2015), conflict may refer to many things including the conflict process, cultural conflict, ethnic conflict, organisational conflict, role conflict, social conflict, workplace conflict and armed conflict among others. This paper is limited to industrial conflict in an attempt to map out the impact of industrial conflict on employees' performance in an organisation. It is also worthy to note that the other types of conflict may also constitute the types and/or causes of conflicts in organisations. Akanji (2005) opined that constructively managed conflict induces a positive performance, while destructively managed conflict heats up the work environment to bring about dislocation and polarisation of the entire group with reduction in productivity and job performance.

Conflict is a struggle over values and claims to scarce status, power and resources in which the aims of the opponents are to neutralize, injure or eliminate the rivals. Kazimoto (2013), mentioned that workplace conflict is described as the presence of discord that occurs when goals, interests or values of different individuals or groups are incompatible and frustrate each other's attempt to achieve objectives in an organisation. Adomie and Annie (2005), stated that a communication process and an inevitable consequence of transactional relationship manifesting in disagreement and dissonance with and between individuals and groups in the work-environment. In this context, workplace conflict is a fact of life in any organisation as long as people will compete for jobs, power, recognition and security.

\subsubsection{Sources of Organisational Conflict}

In order for conflict to occur, certain conditions must exist. It is thus imperative to understand the underlying conditions that can course conflict. In the words of Fajana (1995), conflicts can arise over a multiple of organisational experiences, such as incompatible goals, differences of values and philosophies or disputes over shared resources. Conflict is perception, so it begins when someone believes that another might obstruct his or her efforts. Conflict could arise because of the employer's quest to maximise profit while the workers representatives are out to ensure continuous improved condition of living for their members. Conflict could also arise as a result of failure to honour agreed items on collective bargaining. Damachi (1999) emphasised those workers' rights and employers' prerogatives which when trampled upon, could cause conflict. These include pay, condition of services and so on.

Armstrong (1990), he identified changes as another cause of conflict. Changes according to him are always with us but it is not always welcome. Resistance to change is natural and it arises because of habit once established, few of the unknown, conformity to customary expected ways of behaviour, misunderstanding of 
implications of change and individual differences. Unless, it is well managed, he said, it could lead to conflict or even crises. Other causes of organisational conflict are competition for scarce resources, status in congruency, win-lose situations, the need for change, ambiguous rules and communication problems among others.

Positive outcomes of conflict are: Better ideas are produced, people were forced to search for new approvals, long standing problems surfaced were dealt with, people were forced to clarify their view, the tension stimulated interest and creativity, and that people had a chance to test their capacities. Negative outcomes of conflict include: Some people felt defeated, distance between people increased, a climate of suspicion and distrust developed, people and departments that needed to corporate looked after only their own narrow interests, persistence-active or passive developed were team work was needed, and that some people left because of the turmoil.

\subsubsection{Types of conflicts in organisations}

Ekong, (2000), distinguished between two types of conflict in organisations. These are individual conflicts which can arise as a result of one employee feeling aggrieved and collective conflict which may originate from an individual employee or many results from a disagreement between the union and management. He went on to say that in some cases, a conflict that begins as an individual conflict can develop into a collective conflict. Generally, conflicts involving an individual are ever having his rights that is, what he thinks he is entitled to as an employee in his workplace.

Collective conflicts are concerned mainly with economic matters except in cases of individual conflicts. The conflict may arise either because of a break down in collective agreement on misinterpretation of collective agreement reached or other cases like non-implementation of the whole or parts of the agreement.

Accordingly, individual conflict arises when an employee considers that he has been maltreated or deprived something that he is legitimately entitled to or that some rights of his has been breached. This may arise from unfair disciplinary measure taken against the individual, lack of promotion opportunities for him, deprival of annual increment, among others. This conflict, unless properly investigated can have adverse effects on the employee concerned. On the other hand, collective conflict arises either from misinterpretation of collective agreement or non- implementation of the whole or parts of the agreement. It may also result from break down of collective bargaining.

Dunlop (2002) while agreeing with this expression, remarks that organisational conflicts that arise from collective grievances may also be the result of non-observance of conditions of an individual or disciplinary measure. A large number of conflicts that occur in organisations may be those concerning situations not governed by rules. Such conflicts emanate essentially from individual workers and may be because of an alleged ill-treatment of the workers by his boss or the result of some claimed right.

According to Rahim, (2015), organisational conflict may be classified as intra organisational (conflict within an organisation) or inter-organisational (conflict between two or more organisations.

Intra-organisational conflict may be classified on the basis of level (individual, group, and so on) at which it occurs. On this basis, intra-organisational conflict may be classified to personal, interpersonal, intragroup and intergroup.

i. Intra-personal conflict: This type of conflict occurs when an organisational member is required to perform certain tasks and roles that do not match his or her expertise, interests, goals and values.

According to Kelly (2015), intra-personal conflict occurs within an individual when the individual experiences internal conflict in choosing between incompatible roles.

ii. Inter-personal conflict: It refers to conflict between two or more organisational members of the same or different hierarchical levels or units. This always superior-subordinate type of conflict. Inter-personal conflict often arises from differences in individuals' perceptions, personalities, orientations, attitudes, values or status (Kelly 2015).

iii. Intra-group conflict: This is known as intra-departmental; conflict. It refers to conflict among or between two or more sub-groups within a group in connection with its goals, tasks, procedure and so on. Such conflict may occur as a result of incompatibilities or disagreements between some or all the members of a group and its leaders. James and Jones (2005), observed that departmentalization in organisations create an environment that increased volatility due to stiff competition of scarce resource or due to lack of effective representation and recognition in terms of the value they add to the business. According to Ogboma and wilkinson (1990), poor leadership leads to high level of apathy among employee and this is manifested in a variety of negative behaviour e.g. restlessness and disruption of delivery. Weiner (2001), pointed out that the larger the organization the more differentiated and the more likely it is that negative conflicts will arise as different departments compete for unlimited resources. And these hamper employee's effectiveness.

iv. Inter-group conflict: This is known as interdepartmental conflict. It refers to conflict between two or more units or group within an organisation. Conflict between line and staff, production and marketing and headquarters and field staff are examples of this type of conflict. One special type of intergroup 
conflict is between labour and management

v. Inter-organizational conflict: Conflict between organizations is labeled as inter-organizational conflict. This arose when there is high level of competition between two firms or organizations. Swedburg, (2003), said that inter organization conflicts often occur between management and workers unions when they differ in the implementation of strategic policies and programmes of their respective organization. Gross and Guenerro, (2000), were of the opinion that these types of conflicts must be handled in a positive way in order to make it beneficial to the employees and the organization. Organizations must avoid adopting unethical practices to resolve such conflicts.

According to Robins, (2003), inter organizational conflicts occur when members engage in activities that are incompatible with those of their colleagues within their network, members of other collectivities or unaffiliated individuals who utilize the services or products of the Organization.

\subsubsection{Causes of Industrial conflict}

When people work together, conflict becomes a part of doing business, it's a normal occurrence in any workplace. Notably, managers spend their quality time settling conflict in the workplace. In any organisation, there are many causes of conflicts. According to Henry (2009), conflict within an individual arises when a person is uncertain about what task he is expected to do. If not clearly defined by the supervisor or the person in charge. Again, if tasks of individuals working as a group are not clearly defined by the management they will lead to conflict. In essence, management set tasks that are ambiguous and this always result to conflict as workers are not quite sure of what to do. Conflicts between individuals may result from role related pressure. Conflicts could occur between individuals and groups if the goals are not specified for the individuals within the group (Duke, 1999). This, shows that every individual in a team must be abreast of the goals set for a task if not conflict is bound to happen.

Fashina, (2001), attributed the causes of industrial conflict to policy inconsistencies and wrong placement in organisational priorities on the part of the management. When employers place higher premium on capital input far above the workers without appreciating that workers make the employers productive, would result to industrial rancour. This means that poor remuneration may be a strong cause of industrial conflict. Low level of workers' motivation with respect to remuneration has been a bone of contention between the workers and the employers. Kumar (1995), was of the opinion that conflict occurs because of the asymmetric degree of interdependence that affects the level of trust and commitment of the group. Asymmetric interdependence occurs when parties have different levels of dependence among each other. That is, in one same group individuals can depend on people that in turn show independence in relation to them.

According to Hotepo, et al (2010), conflict usually arises because of lack of resources, different expectations, competition, and lack of co-operation among workers, interdependence, as well as communication problems in many organisations in Nigeria. Obasan, (2011) identified unacceptable terms of employment, poor human relations between management and workers, non- consultation with employees before making key decision affecting workers, anti-union posture of management and lack of effective mechanism for prevention of conflict as multiple causes of conflict in an organisation.

\subsubsection{Reasons for Conflicts}

Jung, (2003) declared that conflict is clearly associated with power and can emerge when goal achievement of an organisation is avoided. It is also believed that people are aware of the factors that generate conflicts such as scarcity, obstruction and incompatible interests or goals. Conflict can also be broken out when one party avoids the goal achievement of the other one. However, he opined that it is probable that causes for conflicts are not highly correlated with goal and objective achievement in situations of routine behaviour where procedures are well defined and environment is stable. In these circumstances, conflict variables are probably more related to personality, autonomy reasons, functional interdependence and status.

Some of the reasons that justify conflict escalation according to (Ikeda et al, (2005) are: (i) as departments grow, people lose contact with other departments, or yet, members of a department start to think differently from other areas; (ii) the increase of emphasis in the financial measures as a tool for motivation for managers and the establishment of different profit centers inside an integrated business system end up creating many conflicts; (iii) the increasing rise of emphasis in functional specialisation, politics of promotion and recruiting reinforce the isolation of departments, generating conflicts; (iv) today there is more room for workers to show criticism among each other, while this freedom of speech can be beneficial for society as a whole, in organisational context can be transformed into conflicts and (v) consumers demand lower prices, better quality in products and services, creating pressures so that departments work more effectively which can result in conflicts among departments.

Another reason pointed by for Kumar et al, (1995), the occurrence of conflicts is the asymmetric degree of interdependence that affects the level of trust and commitment of the groups. Asymmetric interdependence occurs when parties have different levels of dependence among each other. That is, in one same group some individuals can depend on people that, in turn, show independence in relation to them. In total interdependence, on the other hand, individuals are totally dependent on one another. Kumar et al, (1995), stated that those 
relationships with total interdependence have less conflict than the ones with asymmetric interdependence. For Jung, (2003) conflict is smaller in highly dependent relationships because, in general, the dependent party conforms itself that it cannot alter the situation and accept the leader's power.

\subsubsection{Settlement of Conflict}

Conflict should be settled in an organisation to avoid it from degenerating to unhealthy atmosphere. The methods of settlement of conflicts generally include:

i. Investigation: this is conducted by a board or court appointed by the government, it may be voluntary or compulsory. If the investigation is conducted on an application by either or both parties to dispute, it is voluntary.

ii. Mediation: Another attempt to settle dispute is mediation. In this method, an outsider assists the parties in their negotiation. It takes place with the consent of both parties. The mediator performs the messenger's job for both parties and he neither imposes his will nor his judgment upon the parties.

iii. Conciliation: The main objective of a conciliation is to reunite the two-conflicting group in the industry in order to avoid interruption of production, conciliation is a process by which representatives of both workers and employers are brought together before a third party with a view to persuading them to arrive at some sort of agreement or settlement.

iv. Arbitration: If the two parties to dispute fail to come to an agreement, either by themselves or with the help of a mediator, conciliator, who agrees to submit the dispute to an impartial authority, whose decisions, they are ready to accept.

Where the trade unions are weak to settle the dispute, the method of compulsory Arbitration or adjudication is used.

\subsubsection{Conflict resolution approaches}

Inside the business world the ability to resolve conflicts is an invaluable resource. The need for effective conflict resolution practices is present in all areas of any society. Businesses, governments, family life all require a certain level of cooperation in order to function effectively. Conflict management strategies should be designed to bring about peaceful coexistence among workers and employers, promote stability in the organization and promote performance. Lathan (1994) agreed that conflict resolution implies reduction, elimination or termination of conflict.

Negotiation, bargaining, mediation and arbitration are conflict resolution mechanism used to stem down the effect of conflict in an organisation. Management needs to be proactive in the management of conflict and this can be done through strategic planning to prevent constant occurrence of conflict. It needs long term strategies and policies whose impact will prevent the emergency of conditions that give rise to conflict in an organization with its effect impacts on employees' performance. Those strategic plans and policies are fundamental to all organizations and in the society.

According to Lyon (2001) there are disagreement on how to define the scope of preventive diplomacy and utility of various tools and strategies that may be employed to manage conflicts. However, he insisted that preventive diplomacy, arbitration, negotiations and mediation are timely preventive measures that should be utilized for moderating conflicts. Jehn (1994) indicated that conflict emergence should be addressed and vigilance maintained to forestall adverse effect on the business at an early stage. According to Wenner (2001) dominant and avoidance conflict approaches creates more conflict among managers specifically during corporate meetings and general discussions on organizational objectives and goals. The phenomenon also takes place whereby useful and important decisions are at offing stage. For example, during organizational restructuring, downsizing and reorganization of business operations. Gavin (2005) and Gerzon (2006) concurred that conflict management strategy has gained its strategic relevance in modern organizations than ever before due to its value proposition. Armstrong (2006) affirmed that since people are the sources of strategic options, reservoirs of innovation and creates solutions for business problems and challenges unlike other organization resources; they should be supported by work place practices which will enable them to deliver their unique value.

Jones and George (2003) observed that there is no one source of organizational conflicts just like it is the case in social life where conflicts do occur. While conflicts in the society are managed by family members, friends and relatives, organizations should also have the capacity and capability to do the same. In Organisations, conflicts need to be resolved by management to ensure employees are not distracted from their work and thereby adding value to the organization. Unfortunately, conflicts are rarely resolved easily (Baker et al. 1987). All these forms of conflicts and resolution approaches are intertwined and cannot be separated when studying work place conflicts. Indeed, this is the reason why progressive organizations have changed their strategic approach from conflict management to conflict resolution (Brian et al, 2001). The idea is to strategically manage conflicts at all cost and create an organization that is conducive for work. Jones and George (2003), ascertained that work place conflicts have both negative and positive outcomes to the individual employee and the organization. It can occur within groups (intra-group conflict) or among organizations (inter-group conflict) and both largely affect employee performance. Although theoretical and empirical research has largely increased knowledge of intra- 
group and inter-organizational conflict, there are three main areas where sufficient knowledge sorely missing in solving workplace conflicts and its effects on employee performance: (i) There is lack of more theoretically driven empirical research that captures the increasingly dynamic and complex character of intra-group and interorganizational conflict especially in an international context; (ii) there is insufficient theoretical and empirical research examining organizational and work-related practices of governance and policy making and; (iii) there is inadequate empirical research based on theory covering work-related differences resulting from organizational conflict across national boundaries and in multinational entities within national boundaries. In addition, while great attention has been given to the destructive potential of conflict, little attention is given to the opportunities that emerge from intra-group and inter-organizational conflict. Consequently, we have an incomplete picture of the way new work place conflicts resolution are to be developed.

\subsection{Employees Performance in Organisation}

The traditional human resource management approach to enhancing workers performance has centred on the assessment of past performance and the allocation of reward. That is, rewards were provided in exchange for performance. It should be very important that workers' performance improvement is something that should also bother the management. Performance therefore becomes stereotyped as something of no intrinsic interest to the person doing the work. It is critical that the organisation selects the most useful measure of performance for the organisation as a whole and for the individuals within it. Single measure is unlikely to be sufficiently robust. Kaplan and Norton (1992), argued convincingly that the mix of measures which an organisation should use to assess its workers performance should be based around four different perspectives:

i. Financial Measures: Such as sales growth, profits, cash flow and increased market share

ii. Customer Measures: That is, the customer perspective, which looks at, for example, delivery time, service quality, product quality.

iii. Internal Business Measures: Cycle time, productivity employee skills, labour turnover.

iv. Innovation and Learning Perspective: Including such elements as ability to innovate and improve. The focus must be on what is achieved: results are what count.

\subsection{Research Methodology}

This presents the methodology approach employed to achieve the study aims and objectives. In essence, it presents the research design, population of the study, sampling techniques and the data collection method employed in this study.

\subsection{Population and sampling technique}

The population of the study is made up 3761 staff members across all the offices of Ikeja Electricity Company in Lagos. This organisation was preferred for investigation in the study due to its key roles within the service industry. In selecting the respondents in this study, stratified sampling method was adopted to select a sample of 100 employees which served as the final units of the study sample.

\subsection{Data collection instrument}

Data was collected using structured questionnaires because it enabled the researcher to easily collect the required information within a shorter period of time. Questionnaires were easy to administer and easy to obtain information from key people while giving respondents greater freedom in their anonymity

\subsection{Data analysis}

The results were analysed using descriptive and inferential statistics such as frequencies and percentages. The researcher applied correlation analysis to measure the degree of relationship between the independent variable and the dependant variables. Frequencies, percentage mean scores were used in analysing the data with mean scores ranging on a 5 Likert scale (1 strongly disagree, 2 disagree, 3 neutral, 4 agree, 5 strongly-agree.

\subsection{Findings and Discussions}

The response rate of the questionnaires was $90 \%$. The high response rate achieved was attributed to the initial pilot test that enabled the researcher to make proper logistical plans for questionnaire distribution and collection.

\subsection{Respondents' characteristics}

The gender of the respondents was $62 \%$ male and $38 \%$ female. This reflects that the industry has more male employees than female. The level of education of the respondents was PhD 1\%, M.Sc. 4\%, B.Sc. 44\%, HND $33 \%$, NCE/OND 11\%, SSCE 5\%. From this, it can be concluded that the Private sector is keen on recruiting educated employees which makes them well informed. Amongst the respondents, $33 \%$ are between $20-30$ years, $28 \%$ between $31-40$ years like those who are $41-50$ years old. Those who are 51 years and above constitute a 
mere $11 \%$. From the analysis, the Ikeja Electricity Company Plc has a relatively young people in its establishment.

Table 1: Intra group conflicts and employee performance

\begin{tabular}{|l|l|l|l|l|l|}
\hline Categories & $\begin{array}{l}\text { Strongly } \\
\text { Disagree }\end{array}$ & Disagree & Neutral & Agree & $\begin{array}{l}\text { Strongly } \\
\text { Agree }\end{array}$ \\
\hline & $\%$ & $\%$ & $\%$ & $\%$ & $\%$ \\
\hline Change in management style & 11 & 17 & 11 & 17 & 44 \\
\hline Wage differentials & 6 & 11 & 6 & 22 & 55 \\
\hline Team conflicts & 11 & 6 & 11 & 33 & 39 \\
\hline Management policies & 2 & 9 & 13 & 31 & 44 \\
\hline Team conflicts & 11 & 6 & 11 & 33 & 39 \\
\hline Role definition & 17 & 11 & 6 & 22 & 44 \\
\hline Mean & 9.4 & 10.8 & 9.4 & 25 & 44 \\
\hline Standard Deviation & 5.68 & 4.02 & 3.21 & 6.75 & 5.89 \\
\hline Source: Fiend
\end{tabular}

Source: Field survey, 2018

4.2 Intra- group conflicts and their effect on employee performance

From table 1, intra-group conflicts were found to affects employee's performance by majority of the respondents. Average of $45 \%$ of the respondents strongly agreed that some of the factors reviewed are the cause of organizational conflict. Wage differential factor was found to the main factor of conflict which affect employees' performance with $55 \%$ of the respondents strongly agreed. Other factors analysed that were also strongly agreed to by the respondents are; poor role definition, ineffective application of human resource policies and change management which were all strongly agreed to $\mathrm{b} 44 \%$ of the respondents. Group conflict was rated by $39 \%$ strongly agree. These factors greatly contribute to development of intra conflict in the organization which most of the respondents strongly agreed as affecting their performance.

Table 2: Inter-organisation conflict and employee's performance

\begin{tabular}{|l|l|l|l|l|l|}
\hline Categories & $\begin{array}{l}\text { Strongly } \\
\text { disagree }\end{array}$ & Disagree & Neutral & Agree & $\begin{array}{l}\text { Strongly } \\
\text { agree }\end{array}$ \\
\hline & $\%$ & $\%$ & $\%$ & $\%$ & $\%$ \\
\hline Negotiation procedures by the parties & 11 & 17 & 6 & 44 & 22 \\
\hline $\begin{array}{l}\text { Relationship between Ikeja Electric \& Generator } \\
\text { sellers Association }\end{array}$ & 44 & 22 & 6 & 17 & 11 \\
\hline Management / union relations & 6 & 11 & 17 & 22 & 44 \\
\hline Intransigent unions & 6 & 11 & 6 & 33 & 44 \\
\hline Disciplinary management & 11 & 6 & 2 & 31 & 50 \\
\hline Mean & 15.6 & 13.4 & 7.4 & 29.4 & 34.2 \\
\hline Standard Deviation & 16.07 & 6.19 & 5.64 & 10.45 & 16.80 \\
\hline
\end{tabular}

Source: Field survey, 2018

4.3 Inter- organizational conflicts and their effect on employee performance

According to the findings on table 2, majority of the respondents agreed that the key factors causing inter organizational conflicts affect their performance. Disciplinary management was ranked at 50\% which indicate it was the most dissatisfying factor and the highest contributor to poor employee performance. This was followed by poor management and union relations, and intransigent union where an equal share of $44 \%$ strongly agree. The findings further indicated that $44 \%$ of the respondents agreed that poor negotiation procedures affect employee performance while a mere $22 \%$ were of the view that it does not affect performance. This probably represents management staff who are not members of the union. The mean of 34.2 shows that interorganizational conflicts affect performance of the employees.

Table 3: Conflict resolution approaches and employees' performance

\begin{tabular}{|c|c|c|c|c|c|}
\hline Conflict resolution approaches & $\begin{array}{l}\text { Strongly } \\
\text { disagree }\end{array}$ & Disagree & Neutral & Agree & $\begin{array}{l}\text { Strongly } \\
\text { agree }\end{array}$ \\
\hline & $\%$ & $\%$ & $\%$ & $\%$ & $\%$ \\
\hline Conflict procedures & 2 & 9 & 9 & 31 & 49 \\
\hline $\begin{array}{l}\text { Organisation's failure to stick to grievance } \\
\text { procedure }\end{array}$ & 9 & 18 & 18 & 15 & 40 \\
\hline $\begin{array}{l}\text { Failure of the union to follow collective bargaining } \\
\text { agreement }\end{array}$ & 9 & 13 & 9 & 11 & 58 \\
\hline Staff involvement that policy affects & 4 & 7 & 11 & 40 & 38 \\
\hline Dialogue policy affect performance & 20 & 27 & 11 & 20 & 20 \\
\hline Mean & 8.8 & 14.8 & 11.6 & 23.4 & 41 \\
\hline Standard Deviation & 6.98 & 8.01 & 3.71 & 11.93 & 14.18 \\
\hline
\end{tabular}

Source: Field survey, 2018 


\subsection{Conflict resolution approaches and employee performance}

On the issue of the effect of conflict resolution approaches on employee's performance variable as tabulated on table 3,58\% of the respondents strongly agreed that failure by Management and the Union to follow the Recognition Agreement in solving labour issues greatly affects their performance. Another 49\% strongly agreed that lack of effective conflict handling policy adversely affect their performance. Poor staff involvement in policy decision making was ranked at $38 \%$ while poor grievance procedure at $40 \%$. It's quite interesting to note that $27 \%$ of the respondents were of the view that dialogue policy has little significance on employee performance while $11 \%$ were undecided.

\subsection{Conclusion}

According to the results, it is clear that work place conflicts exist in the private sector and have adverse effects on employee performance. Again, it is notable that there is no cordial relationship between Management and the Unions. According to the research objectives, it was found that poor management of factors leading to intra and inter conflicts as well as poor conflict resolution approaches greatly affect employees' performance. In this case it is the responsibility of the management to ensure that the company has effective policy framework that will address conflicts and create harmonious relationship with the Unions. This may to some extent minimize work place conflicts in the organization and increase employees' performance. To maintain an industrial harmony, the human resource should come up with policies and strategies, and set standards that are specific, measurable, achievable, and realistic. There should be good communication following from the top hierarchy to the least subordinate in the organisation. Further, from the empirical findings, it is clear that employees are adversely affected by work place conflicts in terms of their performance hence an organisation with minimum conflict increase their performance. However, it is observed that work place conflicts do have positive effect to both employee and organization as it brings about innovation, creativity and quality decision making. However, Managers, Employees and the Unions should work together towards achieving the positive effects of conflicts rather than the negative.

\section{References}

Akanji, I. (2005). Perspectives in Workplace Conflict Management and New Approaches for the Twenty first Century. In Albert I.O (Ed.), Perspective on Peace and Conflict in Africa: Essays in Honour of Gen. Abdusalam, Abubakar, Ibadan: John Arches Publishers.

Adomi, E. and Anie, S. (2005). Conflict Management in Nigerian University Libraries. Journal of Library Management, 27(8), 520-530.

Amason, A. C. (1996). Distinguishing the Effects of Functional a Dysfunctional Conflict on Strategic Decision Making: Resolving a Paradox for Top Management Teams. Academy of Management Journal, 123-148

Armstrong, M. (1990). A Hand Book of Paper Resources. Paper Back Edition.

Azamosa, O. (2004). Industrial Conflict in Nigerian Universities: The case of the Academic Staff Union of the University Teacher's Strike of December2002 - June 2003. Dept. of Sociology, Anthropology and Applied Social Sciences: Bristol University.

Creswell, J. (2008). Research Design: Qualitative, quantitative, and mixed methods approach. New Jersey: Sage Publications.

Crowther, D. and Lancaster, G. (2012). Research methods. New Jersey: NJ Wiley.

Crouch, C. (1982). Class conflict and industrial relations crisis. London: Heinemann

Damachi, U.G. (1988). Creating Industrial Peace in Nigeria" in Damachi U.G and Tayo Fashoyin (eds.). Contemporary Problems in Nigerian Industrial Relations.

Duke, C. (1999). Organisational conflict affecting Technology and Commercialisation from non-profit laboratories. Journal of Product Band management 4 (5) 5-15

Dunlop, J. (2002). Strategic Management Approach. London: Bolten Press.

Ekong, E. E. (2000). Management styles in Nigerian Universities under Military Rule and the Challenges of Democracy. How Democratic can Universities Be?

Esquivel, M. A. and Kleiner, B, H. (1997). The importance of conflict in team work effectiveness. Team Performance Management, 3 (2), 89-96

Fajana, S. (1995). Industrial Relations in Nigeria: Theories and Features. Lagos: Panaf Press Ltd.

Fajana, S. (2002). Industrial relations in Nigeria: Theory and features (2nd Edition). Lagos. Labofin and Company.

Fajana, S. (2009). Conflict tactics and strategies of Nigerian trade unions: convergence, diversity and implication. Nigerian Journal of Personnel Management, 4 (1), 23-28

Fashina, D. (2001). "Nigerian Tertiary Education: What Future" in Jegede, S, Ale. A. and Akinola (eds.), Nigeria's Tertiary Institution and Human Rights: Committee for Defence of Hunan rights (CHDR), Pp. 1824 
Gross, M. A. and Guererro, L. K. (2000). Managing Conflict appropriately and effectively. An application of the competence model to organisational conflict styles International Journal of Conflict Management: London

Henry, O. (2009). Organisational Conflict and its effects on Organisational Performance. Research journal of Business Management. 2 (1), 16-24

Hotepo, O., Asokere, A., Abdul-Azeez, I., \& Ajemuigbolohun, S. (2010). Empirical Study of the effect of Conflict on Organisational Performance in Nigeria. Business and Economic Journal, 15 (1)

Ikeda, A. A, Veludo-de-Oliveira \& Campomar, M.C. (2005). Organizational conflicts perceived by marketing executives. Electronic Journal of Business and Organization Studies, 10 (1): 22-28

James, L. R., and Jones, R. (2005). Organisational Structure: A review of structural dimensions and their conceptual relationships with individual attitudes and behaviour. Organisational behaviour and human performance (16), 40-57.

Jehn, k. (1995). Multi-method examination of benefits and detriment of intra-group conflict. Administrative Sci Q. 40(1), 256-282

Jung, S. (2003). The effects of organizational culture on conflict resolution in marketing. Journal of American Academy of Business, 3: 242-46.

Kaplan, S. and Norton, J. (1992). The Balanced Scorecard: Measures that Drive Performance. Harvard Business Review. (January-February) pp.71-80.

Kazimoto, P. (2013). Analysis of Conflict Management and Leadership for Organizational Change. International Journal of Research in Social Sciences, 3(1), 1625

Kelly, J. (2015). Conflict: trends and forms of collective action. Employee Relations, 37(6), 720-732.

Kumar, N., Scheer, L. and Steenkamp, J. (1995). The effects of perceived interdependence on dealer attitudes. Journal of Marketing Research, 32 (3), 343- 5

Marczyk, G. (2005). Essentials of research design and methodology. Boston: McGraw Hill Publishers.

Obesan, K. (2011). Impact of Conflict Management on Corporate Productivity: A. Evaluative Study. Australian Journal of Business and management Research, 1 (5), 44-49

Ogboma, E. and Wilkinson, B. (1990). "Corporate strategy and corporate culture: The view from the checkout on the management of change in the UK supermarkets industry". Personnel Review, 19: 300-389

Ojielo, M. O. (2002). Managing organizational conflict: a system approach. Ibadan: John Archers (Publishers) Ltd.

Ongori, H. (2009). Organisational conflict and its effects on Organisational Performance. Research Journal of Business management. 2 (1), 16-24

Rahim, M.F. (2015). Managing Conflict in Organisations. Business and Economics ( $4^{\text {thedition}) . ~ T r a n s a c t i o n ~}$ Publishers.

Robbins, J., Roy, W.I., \& Clifford, R.A (1974). Conflict Management in community Group: University of Illinois at Urbana- Champaign, North Central Region Extension Publication, 36-46.

Robbins, S. P. (1978). Conflict Management and Conflict Resolution are not Synonymous Terms. California Management Review, (winter)

Saunders, M., Lewis, P. and Thornhill, A. (2009). Research Methods for Business Students. ( $5^{\text {th }}$ edition) Harlow: Pearson Education Limited.

Swedburg, R. (2003) Principles of Economic Sociology. Princeton, NJ: Princeton University Press

Weiner, J. M. and Leister, S. w. (2001). Applying a term effectiveness framework to the performance of student's case terms: Human Resource Development Quarterly. 12(4), 385-402

Wilson, J. (2010). Essentials of Business Research. California: Sage Publication Inc. 